\title{
INTER- RELATIONSHIP BETWEEN THYROID AND RENAL PROFILE IN OVERT HYPOTHYROIDISM
}

\author{
Mohammed Ali Imtiaz' ${ }^{1}$ Sushith², Prathima M. B3, S. Reshma4, Madangopal5, Francis. N. P. Monteiro ${ }^{6}$
}

${ }^{1}$ Associate Professor, Department of Biochemistry, A. J. Institute of Medical Sciences \& Research Centre, Mangalore, India. ${ }^{2}$ Associate Professor, Department of Biochemistry, A. J. Institute of Medical Sciences \& Research Centre, Mangalore, India. ${ }^{3}$ Assistant Professor, Department of Biochemistry, A. J. Institute of Medical Sciences \& Research Centre, Mangalore, India. ${ }^{4}$ Assistant Professor, Department of Biochemistry, A. J. Institute of Medical Sciences \& Research Centre, Mangalore, India.

${ }^{5}$ Assistant Professor, Department of Biochemistry, A. J. Institute of Medical Sciences \& Research Centre, Mangalore, India. ${ }^{6}$ Professor, Department of Forensic Medicine \& Toxicology, A. J. Institute of Medical Sciences \& Research Centre, Mangalore, India.

ABSTRACT: BACKGROUND: Renal function is altered by thyroid status. Therefore, this study was done to determine the relationship between thyroid and renal parameters in overt type of thyroid dysfunction.

AIM: The aims of this study were to correlate parameters of serum creatinine, creatinine clearance, with serum $\mathrm{T}_{3}, \mathrm{~T}_{4}$ and $\mathrm{TSH}$ in overt hypothyroid cases.

MATERIALS AND METHODS: This Case control study included fifty diagnosed cases of hypothyroidism in the department of Endocrinology, Medicine and Surgery of A J Institute of Medical Sciences \& Research Centre, Mangaluru, of age group 15-75 years. Based on TSH levels, subjects were classified as subclinical hypothyroids and overt hypothyroids. Results were compared with age and sex matched twenty five euthyroids. Serum $\mathrm{T}_{3}, \mathrm{~T}_{4}$ and TSH; Serum creatinine; and Creatinine clearance were estimated and analysed.

RESULTS: The results of the present study were obtained from 75subjects out of whom 25 were controls, 22 were subclinical hypothyroids and 28 were overt hypothyroids. Age distribution of study subjects shows that the mean age was $39.56 \pm 13.019$ for overt hypothyroids. Sex distribution of study subjects shows that majority of overt hypothyroids (78.6\%) were females. Percentage of individuals with altered serum creatinine, and creatinine clearance among overt hypothyroids shows that there were more cases of overt hypothyroids with increased serum creatinine. Hypothyroid cases had decreased renal function. Overt hypothyroids showed statistically significant difference in the levels of serum creatinine, but they did not differ in the levels of creatinine clearance.

CONCLUSION: Hypothyroidism is linked with considerable derangement in biochemical parameters of renal function, necessitating regularl monitoring of renal pararmeters in hypothyroid patients.

KEYWORDS: Creatinine; Creatinine Clearance; Overt Hypothyroidism; Thyroid Hormones.

HOW TO CITE THIS ARTICLE: Mohammed Ali Imtiaz, Sushith, Prathima. M. B, S. Reshma, Madangopal, Francis. N. P. Monteiro. "Inter- Relationship Between Thyroid and Renal Profile in Overt Hypothyroidism". Journal of Evolution of Medical and Dental Sciences 2015; Vol. 4, Issue 91, November 12; Page: 15609-15611, DOI: 10.14260/jemds/2015/2242.

INTRODUCTION: Long standing hypothyroidism causes significant reversible changes in renal function such as decrease in sodium resorption in the proximal tubules, impairment in the concentrating and diluting capacities of the distal tubules, a decrease in urate concentration, and a decrease in renal blood flow and GFR. This is because of hypodynamic state that occurs in hypothyroidism. The altered thyroid function induces a decrease in myocardial contractility and cardiac output. There is increase in peripheral resistance leading to systemic and renal vasoconstriction. This results in decreased renal blood flow causing decrease in GFR, increase in creatinine and a decrease in creatinine clearance.

Financial or Other, Competing Interest: None.

Submission 07-11-2015, Peer Review 07-11-2015,

Acceptance 09-11-2015, Published 10-11-2015.

Corresponding Author:

Dr. Sushith,

Associate Professor

Department of Biochemistry,

A. J. Institute of Medical Sciences \& Research Centre,

Mangalore-575004.

E-mail: drsushith@yahoo.com

DOI:10.14260/jemds/2015/2242.
There is thickening of basement membrane which again causes reduced blood flow to the kidneys, so there is decreased creatinine clearance. ${ }^{1}$ this study intends to correlate parameters of serum creatinine, creatinine clearance, with serum $\mathrm{T}_{3}, \mathrm{~T}_{4}$ and TSH in overt hypothyroid cases.

MATERIALS AND METHODS: This Case control study included fifty diagnosed cases of hypothyroidism in the department of Endocrinology, Medicine and Surgery of A J Institute of Medical Sciences \& Research Centre, Mangalore, of age group 15-75years after Ethical clearance from Institutional Ethical Copmmittee. Based on TSH levels, subjects were classified as subclinical hypothyroids (TSH6.1$19.9 \mu \mathrm{lU} / \mathrm{ml}$ ) and overt hypothyroids ( $\mathrm{TSH} \geq 20 \mu \mathrm{lU} / \mathrm{ml}$ ).

Results were compared with age and sex matched twenty five euthyroids. Diagnosed cases of hypothyroidism of age group 15-75years (50) were included in the study. Age and sex matched euthyroids(25) taken as control subjects. Patients with acute infections, hepatobiliary diseases, renal diseases, diabetes mellitus, heart diseases, myopathies, pregnant females were excluded from the study. 
In all selected individuals about $5 \mathrm{ml}$ of blood was collected in plain tube from large peripheral vein with aseptic precautions after obtaining informed consent. Serum was separated after centrifugation at $3000 \mathrm{rpm}$ for $10 \mathrm{~min}$ and following parameters were estimated: Serum $\mathrm{T}_{3}, \mathrm{~T}_{4}$ and $\mathrm{TSH}$ measured by Chemiluminescence method in Immulite 1000 autoanalyzer.,2,3,4 Serum creatinine measured by Modified Jaffe's method in semiautoanalyzer using commercially available kit. ${ }^{5}$ Creatinine clearance measured using CockcroftGault formula. ${ }^{6}$

Creatinine clearance $\left(\mathrm{ml} / \mathrm{min} / 1.73 \mathrm{~m}^{2}\right)=$

[(140 - age(years) $\times$ weight $(\mathrm{kg})]$

$72 \times$ plasma creatinine $(\mathrm{mg} / \mathrm{dL})$

Correction factor of 0.85 is recommended for females.

Data was analyzed using Analysis of Variance, Bonferroni test, Kruskar Wallis test, Mann Whitney test, Karl pearsons correlation and Chi square test. $\mathrm{P}<0.05$ was considered to be statistically significant.

RESULTS: The results of the present study were obtained from 75 subjects out of whom 25 were controls, 22 were subclinical hypothyroids and 28 were overt hypothyroids. Age distribution of study subjects shows that the mean age was $39.56 \pm 13.019$ for overt hypothyroids. Sex distribution of study subjects shows that majority of overt hypothyroids $(78.6 \%)$ were females. Percentage of individuals with altered serum creatinine, and creatinine clearance among overt hypothyroids shows that there were more cases of overt hypothyroids with increased serum creatinine $(14.8 \%)$ as illustrated in Table 1.

Correlation of $\mathrm{T}_{3}, \mathrm{~T}_{4}$ and $\mathrm{TSH}$ with other parameters in hypothyroids shows positive correlation between $\mathrm{T}_{3}$ and creatinine clearance $(\mathrm{r}=0.361)$ in hypothyroids. It shows negative correlation with serum Creatinine $(r=-0.406)$. The table shows positive correlation of $\mathrm{T}_{4}$ with creatinine clearance $(\mathrm{r}=0.429)$ and negative correlation with serum creatinine $(\mathrm{r}=-\mathrm{0.484})$. Study also shows positive correlation of TSH with serum creatinine $(r=0.510)$ and negative correlation of creatinine clearance $(r=-0.451)$ with TSH. All correlations were statistically significant with $\mathrm{p}$ value $<0.05$ as depicted in Table 2 .

Correlation of serum creatinine, and creatinine clearance in the study groups shows that there was negative correlation of $\mathrm{T}_{3}$ with serum creatinine $(\mathrm{r}=-0.552)$, and with creatinine clearance $(\mathrm{r}=0.396)$. This correlation was statistically significant. The negative correlation of $\mathrm{T}_{4}$ with serum creatinine $(r=-0.596)$ was statistically significant with $p$ value of 0.001 . The positive correlation between $T_{4}$ with creatinine clearance $(r=0.377)$ was not statistically significant in overt hypothyroids. The positive correlation of TSH with serum creatinine $(r=0.351)$ was not statistically significant. The negative correlation of TSH with creatinine clearance ( $\mathrm{r}=-0.264)$ was not statistically significant in overt hypothyroids as elaborated in Table 3; Fig. No. 1, 2, and 3.

DISCUSSION: Hypothyroidism is a graded phenomenon, ranging from very mild cases in which biochemical abnormalities are present but the individual hardly notices symptoms and signs of thyroid hormone deficiency, to very serious cases of life threatening myxodema coma. The transition from the euthyroid to the hypothyroid state is first detected by a slightly elevated serum TSH, caused by a minor decrease in thyroidal secretion of $\mathrm{T}_{4}$ which does not give rise to subnormal serum $\mathrm{T} 4$ concentration.

A further decline in $\mathrm{T}_{4}$ secretion results in $\mathrm{T}_{4}$ value below the lower normal limit and even higher TSH, but serum $\mathrm{T}_{3}$ concentrations remain within the reference range. It is only in the last stage that subnormal serum $\mathrm{T}_{3}$ concentrations are found, when serum $\mathrm{T}_{4}$ has fallen to very low levels associated with markedly elevated serum TSH concentrations. In hypothyroidism, the first stage of subclinical hypothyroidism may progress towards overt hypothyroidism.

This study showed that the mean age group of overt hypothyroids was $39.56 \pm 13.019$. This is in accordance with a study done by Tayal D et al which showed the age group of patients in the study group as $43.4 \pm 2.67$ years and in the control group as $44.1 \pm 3.2$ years. ${ }^{7}$ Prevalence of overt hypothyroidism was high in females with $78.6 \%$ under overt hypothyroidism. This is in accordance with studies done with Sheikh BA et al and Ali M N et al.8,9

The study showed statistically significant negative correlation between $\mathrm{T}_{3}$ and $\mathrm{T}_{4}$ and serum creatinine with $\mathrm{r}=$ 0.406 and $\mathrm{r}=-0.484$ respectively and a positive correlation between TSH and serum creatinine ( $\mathrm{r}=0.510)$ among hypothyroids which is in accordance with the study of Tayal $\mathrm{D}^{7}$ and Prakash A et al ${ }^{10}$. The negative correlation between $\mathrm{T}_{3}$ and $\mathrm{T}_{4}$ and serum creatinine with $\mathrm{r}=-0.552$ and $\mathrm{r}=-0.596$ respectively were statistically significant in overt hypothyroids $(\mathrm{p}<0.05)$ as the hypodynamic state in hypothyroidism reduces the renal function.

There was positive correlation of creatinine clearance with $\mathrm{T}_{3}$, which was statistically significant in overt hypothyroids ( $\mathrm{r}=0.396, \mathrm{p}=0.041$ ). This is in accordance to the study of Tayal D et $\mathrm{al}^{7}$ which says that lack of $\mathrm{T}_{3}$ causes vasoconstriction ultimately leading to reduced glomerular filteration rate. Although the findings of this study may be utilized for the proper management of hypothyroid cases, further studies on more number of hypothyroid cases along with follow up studies are needed to explore the actual differences in the effects of thyroid hormones in subclinical and overt hypothyroids.

\section{REFERENCES:}

1. Kreisman S H, James V H. Consistent Reversible Elevations of Serum Creatinine Levels in Severe Hypothyroidism. Intern Med. 1999; 159: 79-82.

2. Hollander C S, Nihei N, Burday S Z, Mitsuma T, Shenkman L, Blum M. Clinical and laboratory observations in cases of triiodothyronine toxicosis confirmed by radioimmunoassay. Lancet 1972:609-11.

3. Britton K E, Quinn V, Brown B L, Ekins R P. A strategy for thyroid function tests. Br Med J 1975:350-352.

4. Bayer M, Clinical experience with sensitive thyrotropin measurements:diagnostic and therapeutic implications. J Nucl Med 1985; 36:1248-56.

5. Allen. L. C. Creatinine determination. Clin, Chem 1982; 28:555. 
6. Cockcroft Gault M H. Prediction of Creatinine clearance from serum creatinine.

Nephron 1976; 16:31.

7. Tayal D, Chawla R, Arora S et al. Dynamic Changes in Biochemical Markers of Renal Function with Thyroid Status - A Study in Indian Population. Internet Journal of Medical Update 2009; 4(2):36-41.

8. Sheikh BA, Soomro AA, Soomro MA, Pirzado ZA et al. Lipid profile in primary hypothyroidism at Chandka Medical college Larkana.

Medical channel 2009; 15(4):15-18.

9. Ali MN, Ibrahim AM, and Mohamed AB . Prevalence of Thyroid Dysfunction and its Effect on serum lipid profiles in a Murzok, Libya Population. Thyroid science 2008; 3(10):1-6.

10. Prakash A, Lal A K, Negi K S. Serum Creatine Kinase Activity in Thyroid Disorders.

JK Science 2007; 9(1):25-26.

\begin{tabular}{|c|c|c|}
\hline Parameter & Range & $\begin{array}{c}\text { Overt } \\
\text { hypothyroids }\end{array}$ \\
\hline $\begin{array}{c}\text { Serum creatinine } \\
\mathrm{mg} / \mathrm{dl}\end{array}$ & Above normal & $14.8 \%$ \\
\hline $\begin{array}{c}\text { Creatinine } \\
\text { clearance } \\
\mathrm{ml} / \mathrm{min} / 1.73 \mathrm{~m}^{2}\end{array}$ & $\begin{array}{c}\text { Below normal } \\
\text { range }\end{array}$ & $77.8 \%$ \\
\hline $\begin{array}{c}\text { Table 1: Percentage of individuals studied with altered } \\
\text { levels of serum creatinine and creatinine clearance } \\
\text { among overt hypothyroids }\end{array}$ \\
\hline \multicolumn{2}{|c}{} \\
\hline
\end{tabular}

\begin{tabular}{|c|c|c|c|}
\hline & Parameters & r value & P value \\
\hline \multirow[t]{2}{*}{$\mathrm{T}_{3} \mathrm{ng} / \mathrm{dl}$} & Serum creatinine & -0.406 & 0.000 \\
\hline & $\begin{array}{l}\text { Creatinine } \\
\text { clearance }\end{array}$ & 0.361 & 0.002 \\
\hline \multirow[t]{2}{*}{$\mathrm{T}_{4} \mu \mathrm{g} / \mathrm{dl}$} & Serum creatinine & -0.484 & 0.000 \\
\hline & $\begin{array}{c}\text { Creatinine } \\
\text { clearance }\end{array}$ & 0.429 & 0.000 \\
\hline \multirow[t]{2}{*}{$\begin{array}{c}\text { TSH } \\
\mu \mathrm{IU} / \mathrm{ml}\end{array}$} & Serum creatinine & 0.510 & 0.000 \\
\hline & $\begin{array}{l}\text { Creatinine } \\
\text { clearance }\end{array}$ & -0.451 & 0.000 \\
\hline & $\begin{array}{c}\text { Correlation of } T_{3} \\
\text { parameters in }\end{array}$ & pothyroi & other \\
\hline
\end{tabular}

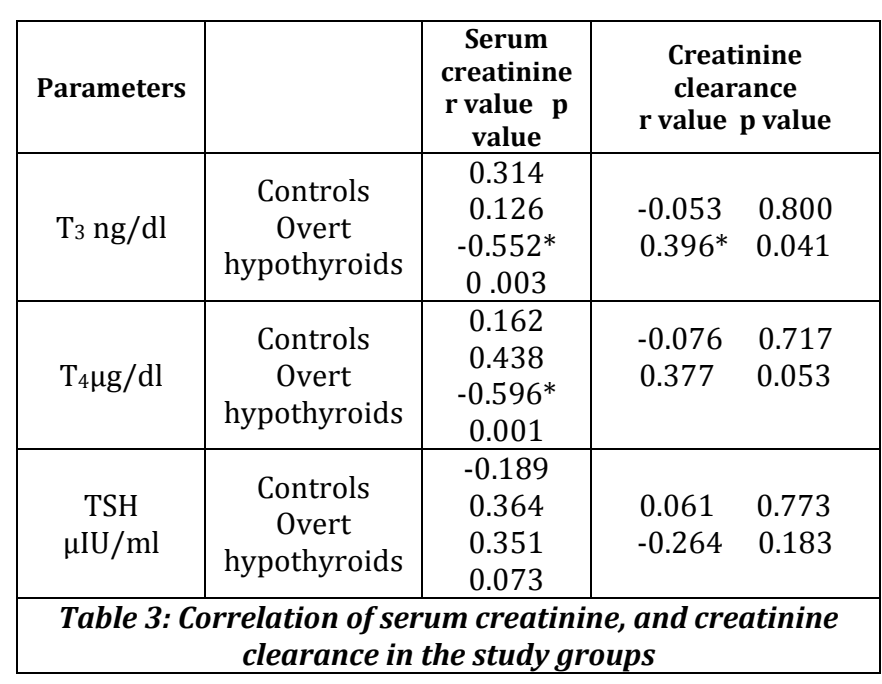

\footnotetext{
${ }^{*} \mathrm{P}$ value $<0.05$
}

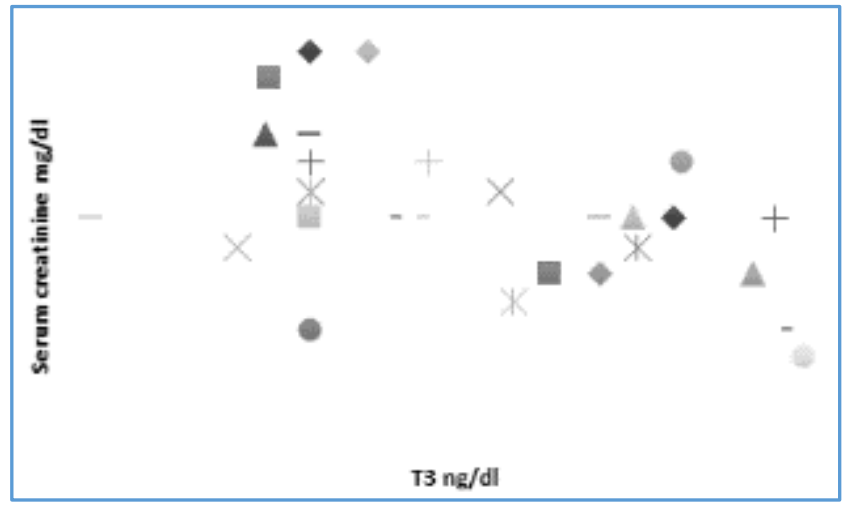

Fig. 1: Correlation of serum creatinine with $T_{3}$ in overt hypothyroids

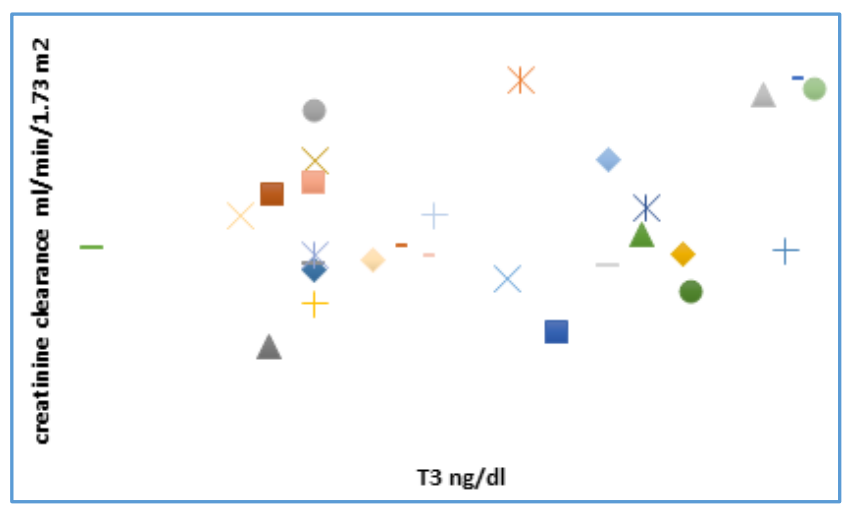

Fig. 2: Correlation of creatinine clearance with $T_{3}$ in overt hypothyroids

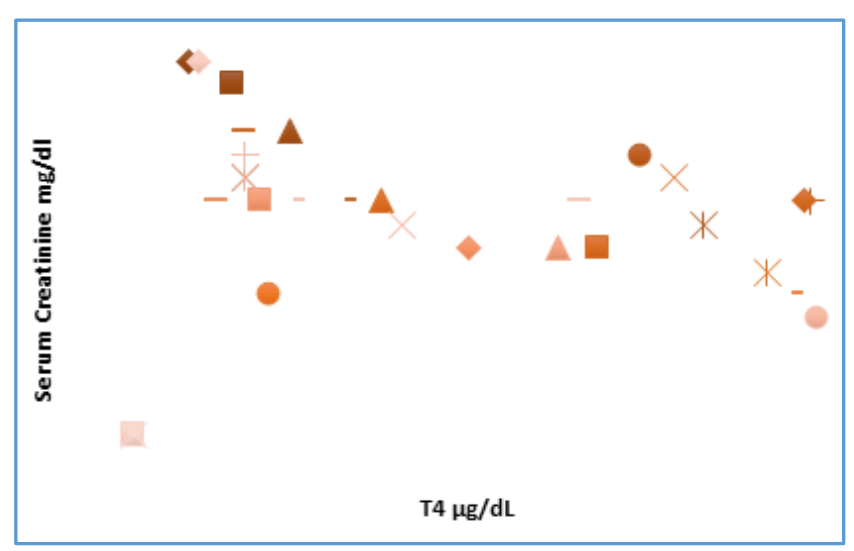

Fig. 3: Correlation of serum creatinine with $T_{4}$ in overt hypothyroids 